Check for updates

Cite this: Mater. Adv., 2022, 3,1224

Received 11th November 2021 Accepted 9th December 2021

DOI: 10.1039/d1ma01057c

rsc.li/materials-advances

\title{
Electroreduction of carbon dioxide to formate using highly efficient bimetallic Sn-Pd aerogels $\uparrow$
}

\author{
Maryam Abdinejad, (D) $\ddagger^{*^{a}}$ Mozhgan Khorasani Motlagh, $\ddagger^{\mathrm{b}}$ Meissam Noroozifar ${ }^{\mathrm{b}}$ and \\ Heinz Bernhard Kraatz (iD) *bc
}

\begin{abstract}
Electrochemical reduction of carbon dioxide $\left(\mathrm{CO}_{2}\right)$ to valuable materials is a promising approach to suppress atmospheric $\mathrm{CO}_{2}$ levels. In order to bring this strategy to a commercial scale, the design of efficient, cost-effective, and robust catalysts is essential. Current advances in $\mathrm{CO}_{2}$ conversion technology use bimetallic components that enhance electrocatalysis via the introduction of binding site diversity. In this work, $\mathrm{Sn}-\mathrm{Pd}$ bimetallic aerogels supported by carbon nanotubes ( $\mathrm{Sn}-\mathrm{Pd} / \mathrm{CNT}$ ) demonstrate selective electroreduction of $\mathrm{CO}_{2}$ to formate in ambient conditions. Amino substituents were introduced as an additional $\mathrm{CO}_{2}$ capture site $\left(\mathrm{Sn}-\mathrm{Pd} / \mathrm{CNT}-\mathrm{NH}_{2}\right)$, further enhancing the electrocatalytic activity and resulting in $91 \%$ formate selectively and a current density of $-39 \mathrm{~mA} \mathrm{~cm}{ }^{-2}$ at $-0.4 \mathrm{~V} v \mathrm{~s}$. $\mathrm{RHE}$. The results demonstrate the potential of alloying $\mathrm{Sn}$ with other earth-abundant metals to promote the electrochemical conversion of $\mathrm{CO}_{2}$ to value-added materials. We believe this study provides valuable insights into the intricate relationship of bimetallic aerogels and shows the potential of the $-\mathrm{NH}_{2}$ group as a facilitator for $\mathrm{CO}_{2}$ capture and conversion that will inspire new forays into the development of competitive catalytic systems
\end{abstract}

\section{Introduction}

Increasing carbon dioxide $\left(\mathrm{CO}_{2}\right)$ levels in the atmosphere are considered as a major contributor to climate change. ${ }^{1}$ Electrocatalytic carbon dioxide reduction reactions $\left(\mathrm{CO}_{2} \mathrm{RRs}\right)$ to value added materials such as formic acid $(\mathrm{HCOOH})$, carbon monoxide (CO), methane $\left(\mathrm{CH}_{4}\right)$, methanol $\left(\mathrm{CH}_{3} \mathrm{OH}\right)$, and ethanol $\left(\mathrm{C}_{2} \mathrm{H}_{5} \mathrm{OH}\right)$, have drawn significant attention to mitigate climate change. $^{2-8}$ Formate, in particular, is valued as an ideal candidate for hydrogen storage and fuel cell processes. ${ }^{9,10}$ However, due to the complexity of its multi-electron reaction pathway and competition with hydrogen evolution reactions (HERs), the reaction is sluggish and hindered by a large activation overpotential. $^{11}$

There has been considerable progress on improving electrocatalytic activity for $\mathrm{CO}_{2}$ reduction by introducing binding site diversity. ${ }^{12}$ Although various metals, such as $\mathrm{Pd},{ }^{13} \mathrm{~Pb},{ }^{14} \mathrm{Bi},{ }^{15,16}$ $\mathrm{Sn},{ }^{17-19} \mathrm{Ag},{ }^{20}$ and $\mathrm{In}^{21}$ themselves demonstrate high selectivity

\footnotetext{
${ }^{a}$ Department of Chemical Engineering, Delft University of Technology, Van der Maasweg 9, 2629 HZ Delft, The Netherlands.E-mail: M.Abdinejad@tudelft.nl

${ }^{b}$ Department of Physical and Environmental Sciences, University of Toronto

Scarborough, 1265 Military Trail, Toronto, ON M1C 1A4, Canada.

E-mail: bernie.kraatz@utoronto.ca

${ }^{c}$ Department of Chemistry, University of Toronto, 80 St. George Street, Toronto, ON M5S 3H6, Canada

$\dagger$ Electronic supplementary information (ESI) available. See DOI: 10.1039/d1ma01057c

$\ddagger$ These authors contributed equally.
}

for formate production, recent reports show that bimetallic alloys of these metals can increase catalytic activity even further. $^{22,23}$ Additionally, Sn-based ${ }^{24-27}$ and Pd-based ${ }^{28,29}$ bime- $^{-}$ tallic catalysts are superior in several aspects where monometallic catalysts are lacking: in reducing large overpotentials and improving surface stability towards $\mathrm{CO}_{2} \mathrm{RR}^{30-34}$

In addition to tailoring the elemental composition affect catalytic performance, increasing the catalytically active surface area is another strategy that can be used to enhance current density. ${ }^{35,36}$ To this end, geometric factors such as metal dispersion, surface morphology, and porosity play a key role. ${ }^{37}$ Aerogels stand out among similar porous structural materials in facilitating electron transport and optimizing catalytically active surface area. ${ }^{38-45}$ Owing to their porous and three-dimensional (3D) structure, they can dramatically enhance mass transport and facilitate $\mathrm{CO}_{2} \mathrm{RR}^{46-48}$ Liu et al. ${ }^{49}$ have reported a Sn nanoparticle-modified 3D carbon nanotube (CNT) aerogel whose unique porous, hierarchical structure was instrumental in increasing current density and effectively enhancing the selectivity of formate production. These studies stress the import of morphology control on the performance of Sn-based catalysts for the $\mathrm{CO}_{2} \mathrm{RR}^{50}$

Knowing that Pd surface is poisoned by $\mathrm{CO},{ }^{51}$ in this project, we took an advantage of Sn surface to enhance the adsorption of $\mathrm{CO}_{2}$, but weakened the $\mathrm{CO}$ binding on Pd, and have designed a series of bimetallic $\mathrm{Sn}-\mathrm{Pd}$ aerogels, to improve their stability and overall catalytic performance through the synergy between 
$\mathrm{Pd}$ and Sn surface for electroreduction of $\mathrm{CO}_{2}$. Aerogels of these bimetallic systems were employed to maximize the surface area of the catalytic layer through the creation of a highly porous nanostructure. ${ }^{4,48}$ Building on previous works, carbon nanotubes (CNTs) were incorporated throughout the aerogel to enhance the electron conductivity of the structure (Sn-Pd/ $\mathrm{CNT}){ }^{52}$ Amine groups have been shown to have a high capability of capturing $\mathrm{CO}_{2},{ }^{53-55}$ and are integrated into our design to serve as an additional $\mathrm{CO}_{2}$ capture site and localized proton source ( $\mathrm{Sn}-\mathrm{Pd} / \mathrm{CNT}-\mathrm{NH}_{2}$ ). Using this design, we could successfully reduce $\mathrm{CO}_{2}$ to formate with $91 \%$ selectivity and current density of $-39 \mathrm{~mA} \mathrm{~cm}^{-2}$ at $-0.4 \mathrm{~V} v$ s. RHE. Comparative studies of these bimetallic systems with their monometallic Sn and Pd aerogels counterparts will be discussed in this work.

\section{Experimental}

A series of 3D Pd, Sn-Pd, Sn-Pd-CNT, and Sn-Pd-CNT- $\mathrm{NH}_{2}$ aerogels were synthesized through a one-pot and surfactantfree technique by reducing $\mathrm{H}_{2} \mathrm{PdCl}_{4}$ and $\mathrm{SnCl}_{2}$ with glyoxylic acid using lyophilization (ESI $\dagger$ Part 3 ). ${ }^{48}$ The spongy, porous morphology characteristic of aerogels was visualized using Scanning Electron Microscopy (SEM) (Fig. 1a, and Fig. S1, ESI $\dagger$ ). The uniform distribution of atoms within the aerogel's structure affirms a homogeneous distribution of corresponding Pd, Sn, N, and C components (Fig. 1b-e). Transmission electron microscopy (TEM) images highlight the structural presence of CNTs in the case of the Sn-Pd/CNT-NH 2 aerogel (Fig. S2, ESI $\dagger$ ).

$\mathrm{X}$-Ray photoelectron spectroscopy (XPS) gives insight into the chemical environments of the bimetallic material, where the two characteristic peaks with the binding energy of $335 \mathrm{eV}$ and $340 \mathrm{eV}$ correspond to $\mathrm{Pd} 3 \mathrm{~d}_{3 / 2}$ and $\mathrm{Pd} 3 \mathrm{~d}_{5 / 2}$ and peaks at 486.1 and $492.5 \mathrm{eV}$ are attributed to $\mathrm{Sn} 3 \mathrm{~d}_{5 / 2}$ and $\mathrm{Sn} 3 \mathrm{~d}_{3 / 2}$, respectively (Fig. 2a, b, and Fig. S3-S9, ESI $\dagger$ ). In the presence of CNTs, a slight upward shift in the binding energy could be indicative of a highly dispersive and synergetic relationship

(a)

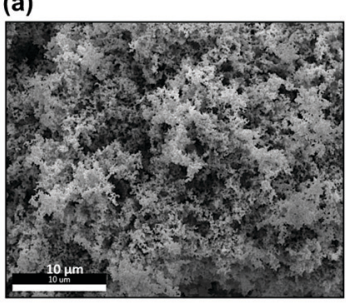

(b) Sn

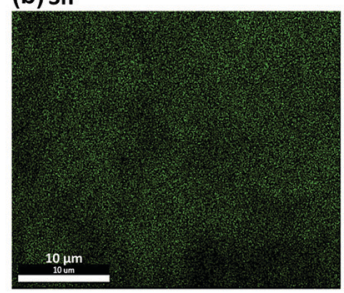

(c) Pd

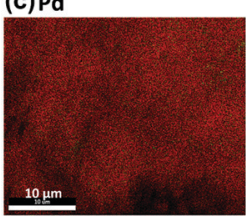

(d) $\mathrm{N}$

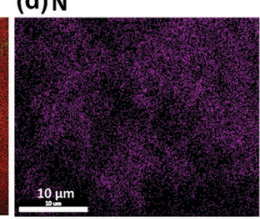

(e)C

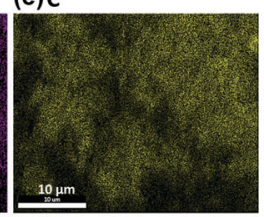

Fig. 1 (a) Scanning Electron Microscopy (SEM) of $\mathrm{Sn}-\mathrm{Pd}-\mathrm{CNT}-\mathrm{NH}_{2}$ aerogel with a scale bar of $10 \mu \mathrm{m}$. (b-e) Atom distribution of Sn, Pd, N, and $\mathrm{C}$, respectively.
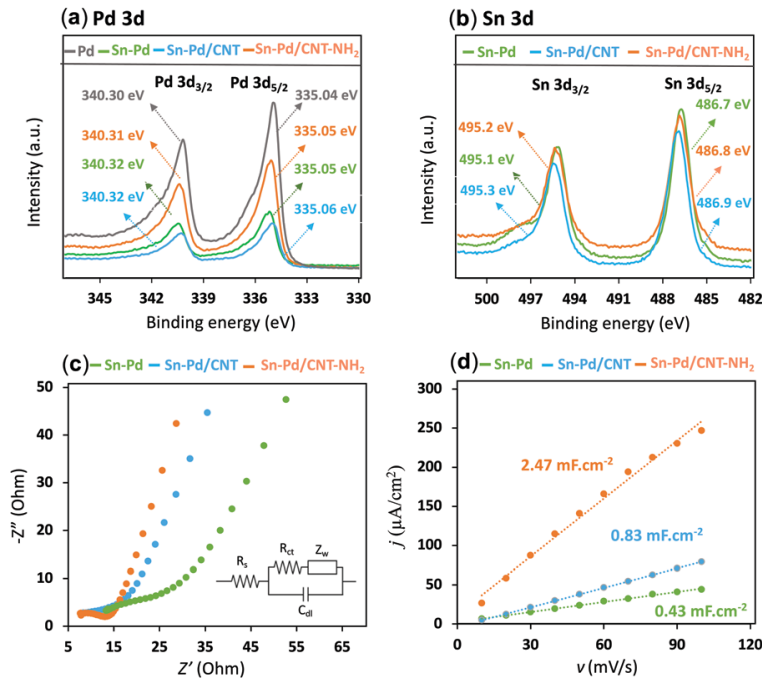

Fig. 2 X-ray photoelectron spectroscopy (XPS) spectra survey comparison of: (a) $\mathrm{Pd} 3 \mathrm{~d}$ spectra of $\mathrm{Pd}, \mathrm{Sn}-\mathrm{Pd}, \mathrm{Sn}-\mathrm{Pd} / \mathrm{CNT}$, and $\mathrm{Sn}-\mathrm{Pd} / \mathrm{CNT}-\mathrm{NH}_{2}$ aerogels; (b) Sn 3d spectra of $\mathrm{Sn}-\mathrm{Pd}, \mathrm{Sn}-\mathrm{Pd} / \mathrm{CNT}$, and $\mathrm{Sn}-\mathrm{Pd} / \mathrm{CNT}-\mathrm{NH}_{2}$ aerogels. (c) Electrochemical impedance spectroscopy (EIS) of Sn-Pd, Sn$\mathrm{Pd} / \mathrm{CNT}$, and $\mathrm{Sn}-\mathrm{Pd} / \mathrm{CNT}-\mathrm{NH}_{2}$ in saturated solution with $\mathrm{CO}_{2}$ and $0.1 \mathrm{M}$ $\mathrm{KHCO}_{3}$ with amplitude of $5 \mathrm{mV}$ in a frequency range from $10 \mathrm{kHz}$ to $0.1 \mathrm{~Hz}$. (d) Current density difference between cathodic and anodic sweeps at $-0.44 \mathrm{~V}$ vs. scan rates in $2.5 \mathrm{mM}\left[\mathrm{Fe}(\mathrm{CN})_{6}\right]^{3-/ 4-}$ and $0.2 \mathrm{M} \mathrm{KNO}_{3}$

between the two materials. ${ }^{56,57}$ The $\mathrm{Sn}-\mathrm{Pd} / \mathrm{CNT}-\mathrm{NH}_{2}$ aerogel, was characterized further by X-ray diffraction (XRD) (Fig. S10, ESI $\dagger$ ). Peaks seen at $40.1^{\circ}, 46.6^{\circ}, 68.1^{\circ}$, and $82.1^{\circ}$ are characteristic diffraction peaks of Pd crystals; whereas, peaks at $26.5^{\circ}$ and $34.4^{\circ}$ belong to $\mathrm{CNT}^{58}$ and Sn which confirm the successful formation of the aerogel. These results are in agreement with previous reports. ${ }^{25,59,60}$

The nature of the charge-transfer resistance in the presence and absence of CNTs was investigated using electrochemical impedance spectroscopy (EIS) (Fig. 2c). The semicircular arcs at the high-frequency regions of the Nyquist plots are characteristic of a capacitance double layer between the electrolyte and the electrode interface; which reflects the charge transfer resistance of an electrochemical reaction $\left(R_{\mathrm{ct}}\right) .{ }^{61}$ The values of $R_{\text {ct }}$ from equivalent circuit fitting for $\mathrm{Sn}-\mathrm{Pd}, \mathrm{Sn}-\mathrm{Pd} / \mathrm{CNT}$, and $\mathrm{Sn}-\mathrm{Pd} / \mathrm{CNT}-\mathrm{NH}_{2}$ are an estimated $23.1,17.9$, and $8.7 \Omega$, respectively. The lower $R_{\mathrm{ct}}$ in Sn-Pd/CNT and Sn-Pd/CNT- $\mathrm{NH}_{2}$ compared to $\mathrm{Sn}-\mathrm{Pd}$ underscore the significant improvement to charge transfer and electrical conductivity the CNT and CNT$\mathrm{NH}_{2}$ offer. ${ }^{62,63}$

The electronic structure of Sn-Pd-based catalysts has been reported previously. The bimetallic Pd-Sn alloys have a unique electronic structure similar to that of noble metals that forms when rehybridization of the Sn sp-orbitals and $\mathrm{Pd}$ d-orbitals occurs. ${ }^{64-66}$ In the case of $\mathrm{Sn}-\mathrm{Pd} / \mathrm{CNT}$ and $\mathrm{Sn}-\mathrm{Pd} / \mathrm{CNT}-\mathrm{NH}_{2}$, the $\pi$-orbitals of CNTs can weakly bond with $\mathrm{Sn}-\mathrm{Pd}$ through hybridization between the carbon $\pi$-orbitals and the high energy d-orbitals of the metals; ${ }^{67,68}$ strengthening the electronic structure and thereby facilitating charge transfer. To further examine the charge transfer of the synthesized aerogels, the 
standard exchange current density $\left(i_{0}\right)$ was calculated using the following equation (eqn (1)): ${ }^{69}$

$$
i_{\mathrm{o}}=\frac{R T}{n F R_{\mathrm{ct}}}
$$

where $R, T, n, F$, and $R_{\mathrm{ct}}$ are the gas constant, temperature, number of electrons involved in the reaction, faradaic constant, and the calculated charge transfer resistance obtained from EIS. The $i_{0}$ values for Sn-Pd, Sn-Pd/CNT, and Sn-Pd/CNT-NH aerogels were calculated as $1.1 \times 10^{-3}, 1.5 \times 10^{-3}$, and $3.0 \times 10^{-3}$, respectively, highlighting the superior charge transfer of the $\mathrm{Sn}-\mathrm{Pd} / \mathrm{CNT}-\mathrm{NH}_{2}$ aerogel. $^{70}$

To shed light on the influence of CNTs and $-\mathrm{NH}_{2}$ on surface area activity, it is important to quantify the electrochemically active surface area (ECSA) of the modified electrode surfaces as described in ESI, $\dagger$ Part 4 (Fig. S11, ESI $\dagger$ ). ${ }^{71}$ The $C_{\mathrm{dl}}$ was estimated by plotting the $j\left(\mu \mathrm{A} \mathrm{cm}{ }^{-2}\right)$ at $-0.44 \mathrm{~V} v s$. $\mathrm{Ag} / \mathrm{AgCl}$ against the scan rate $\left(\mathrm{mV} \mathrm{s}^{-1}\right)$ and it is twice the slopes of linear fit (Fig. 2d). The roughness factor $\left(R_{\mathrm{f}}\right)$ of the electrodes can be calculated using eqn (2): ${ }^{72,73}$

$$
R_{\mathrm{f}}=\frac{C_{\mathrm{dl}}}{60}
$$

where $C_{\mathrm{dl}}$ is the double-layer capacitive current (more detail in ESI $\dagger$ ) and the $C_{\mathrm{dl}}$ of an ideal smooth surface is $60 \mu \mathrm{F} \mathrm{cm} \mathrm{cm}^{-2}$. From eqn (2) and the electrode surface area of $0.071 \mathrm{~cm}^{2}$, the ECSA was calculated using eqn (3):

$$
\mathrm{ECSA}=R_{\mathrm{f}} \times S_{\text {electrode }}
$$

Combining with the CVs results in Fig. S11 (ESI $\dagger$ ) and actual catalyst load on glassy carbon electrode, the ECSA for Sn-Pd, $\mathrm{Sn}-\mathrm{Pd} / \mathrm{CNT}$, and $\mathrm{Sn}-\mathrm{Pd} / \mathrm{CNT}-\mathrm{NH}_{2}$ was calculated as $0.25,0.49$, and $1.46 \mathrm{~cm}^{2}$, respectively. The higher ECSA for the $\mathrm{Sn}-\mathrm{Pd} /$ $\mathrm{CNT}-\mathrm{NH}_{2}$ indicates its larger catalytic activity compared to Sn$\mathrm{Pd}$ and $\mathrm{Sn}-\mathrm{Pd} / \mathrm{CNT}$. The higher ESCA of Sn-Pd/CNT compared to $\mathrm{Sn}-\mathrm{Pd}$ could be due to the greater charge transfer that CNT facilitates between the aerogel and the electrode surface. ${ }^{74-77}$ Further improvement to the ESCA is seen in the case of Sn-Pd/ CNT- $\mathrm{NH}_{2}$, which can be due to enhanced electron-proton transfer of the $-\mathrm{NH}_{2}$ groups. ${ }^{57}$

\section{Results and discussion}

To evaluate the electroactivity of the synthesized complexes, electrochemical reduction of $\mathrm{CO}_{2}$ was studied with linear sweep voltammetry (LSV) in an aqueous $0.1 \mathrm{M} \mathrm{KHCO}_{3}$ solution. A twocompartment electrochemical H-cell comprised of a threeelectrode system with immobilized aerogels on a glassy carbon working electrode (GCE), platinum counter electrode, and a silver/silver chloride $(\mathrm{Ag} / \mathrm{AgCl})$ reference electrode. ${ }^{78}$ To prepare the working electrodes, $10 \mu \mathrm{mol}$ of the synthesized Pd-Sn aerogels were immobilized onto a $0.3 \mathrm{~cm}$ diameter GCE with a catalyst loading concentration of $1.57 \times 10^{-7} \mathrm{~mol} \mathrm{~cm} \mathrm{~cm}^{-2}$ relative to the geometrical electrode area $\left(0.071 \mathrm{~cm}^{2}\right) .{ }^{55}$ To incorporate the CNTs, Sn-Pd and CNTs were dissolved in a
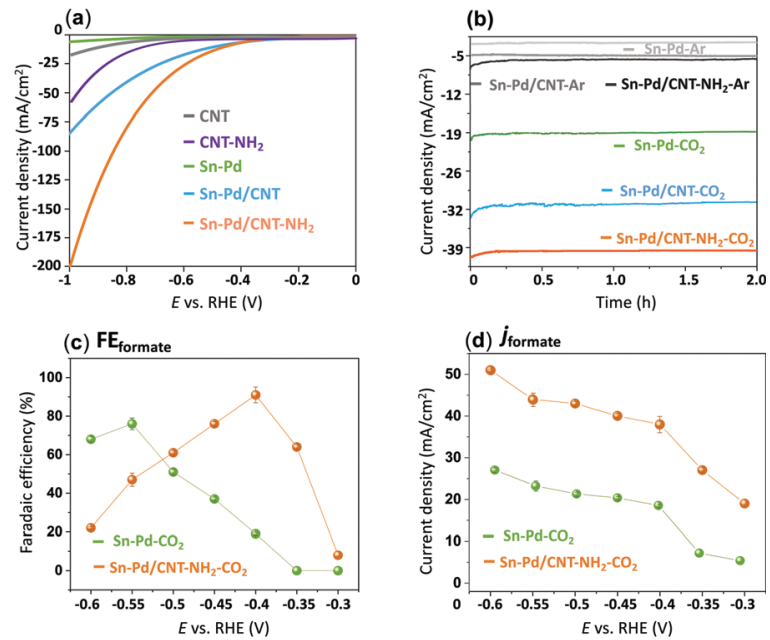

Fig. 3 (a) Linear sweep voltammetry (LSV) comparison of bare CNT, bare $\mathrm{CNT}-\mathrm{NH}_{2}, \mathrm{Sn}-\mathrm{Pd}, \mathrm{Sn}-\mathrm{Pd} / \mathrm{CNT}$, and $\mathrm{Sn}-\mathrm{Pd} / \mathrm{CNT}-\mathrm{NH}_{2}$ in $0.1 \mathrm{M} \mathrm{KHCO}_{3}$; (b) chronoamperometry comparison of $\mathrm{Sn}-\mathrm{Pd}, \mathrm{Sn}-\mathrm{Pd} / \mathrm{CNT}$, Sn-Pd/CNT$\mathrm{NH}_{2}$ in $0.1 \mathrm{M} \mathrm{KHCO}_{3}$ at $-0.4 \mathrm{~V}$ vs. RHE. (c) Faradaic efficiency (FE formate), and (d) current density ( $j_{\text {formate }}$ ) comparison of Sn-Pd, and Sn-Pd/CNT$\mathrm{NH}_{2}$ at $-0.30,-0.35,-0.4,-0.45,-0.5,-0.55$ and $-0.6 \mathrm{~V}$ vs. RHE in $0.1 \mathrm{M}$ $\mathrm{KHCO}_{3}$.

DMF solution and sonicated for 20 minutes to form a homogeneous suspension of $\mathrm{Sn}-\mathrm{Pd} / \mathrm{CNT}$ and $\mathrm{Sn}-\mathrm{Pd} / \mathrm{CNT}-\mathrm{NH}_{2}{ }^{48}$

Fig. 3a compares the LSV of bare CNT and CNT- $\mathrm{NH}_{2}$ with the immobilized aerogels Sn-Pd, Sn-Pd/CNT, and Sn-Pd/CNT$\mathrm{NH}_{2}$ onto GCE in $0.1 \mathrm{M} \mathrm{KHCO}_{3}$ in the presence of $\mathrm{CO}_{2}$. Exposure of the aerogels to $\mathrm{CO}_{2}$ resulted in a dramatic increase to the current density beginning at $-0.67,-0.42$, and $-0.38, \mathrm{~V}$ vs. RHE for compounds Sn-Pd, Sn-Pd/CNT, and Sn-Pd/CNT$\mathrm{NH}_{2}$, respectively, which could be due to either electroreduction of $\mathrm{CO}_{2}$ or HER (Fig. S12, ESI $\dagger$ ). Comparing pristine CNT with $\mathrm{CNT}-\mathrm{NH}_{2}$ in Fig. 3a finds a higher current density and lower potential in the presence of $-\mathrm{NH}_{2}$. This observation aligns with what has been reported previously. ${ }^{54}$ Achieving the highest catalytic activity with the lowest overpotential in the case of $\mathrm{Sn}-\mathrm{Pd} / \mathrm{CNT}-\mathrm{NH}_{2}$ further highlights the to the role of $-\mathrm{NH}_{2}$ in capturing $\mathrm{CO}_{2}$.

The proficiency of the bimetallic Sn-Pds towards $\mathrm{CO}_{2}$ electroreduction was evaluated under chronoamperometric conditions. The experiments were conducted at $-0.3,-0.35,-0.4$, $-0.45,-0.5,-0.55$ and $-0.6 \mathrm{~V} v s$. RHE in $0.1 \mathrm{M} \mathrm{KHCO}_{3}$ for $2 \mathrm{~h}$ under sealed conditions with vigorous magnetic stirring. Formate and $\mathrm{H}_{2}$ were detected as the sole products of the electrochemical $\mathrm{CO}_{2} \mathrm{RR}$ after gas chromatography (GC) sampling of the reaction headspace and ${ }^{1} \mathrm{H}$ NMR and HPLC analysis of the liquid solution. As shown in Fig. S14-S16 (ESI $\dagger$ ), the product distribution is strongly dependent on the applied potential. A greater decrease in $\mathrm{FE}_{\text {formate }}$ was seen at higher overpotentials in competition with an uptick in HERs. ${ }^{54}$

The optimal overpotential for $\mathrm{Sn}-\mathrm{Pd}$ was found to be $-0.55 \mathrm{~V} v s$. RHE, and much lower optimal potential of $-0.4 \mathrm{~V}$ vs. RHE was observed in the case of Sn-Pd-CNT and Sn-Pd/ CNT- $\mathrm{NH}_{2}$ (Fig. 3b). This could be due to the support of the CNT 

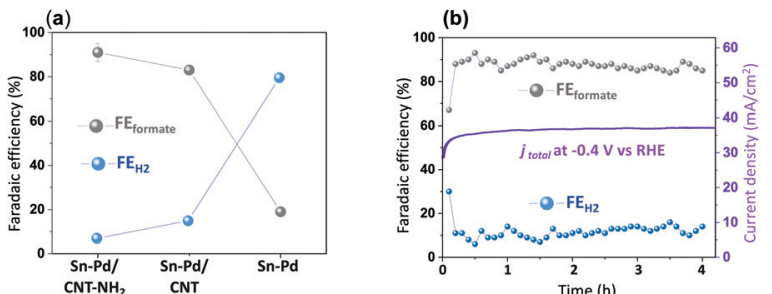

(c)

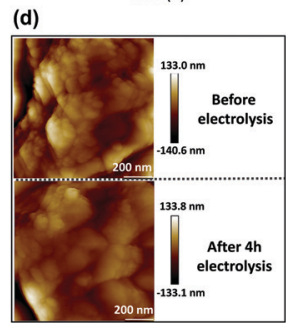

Fig. 4 (a) Faradaic efficiency (FE) and current density ( $j$ ) comparison of $\mathrm{Sn}-\mathrm{Pd}, \mathrm{Sn}-\mathrm{Pd} / \mathrm{CNT}$, and $\mathrm{Sn}-\mathrm{Pd} / \mathrm{CNT}-\mathrm{NH}_{2}$ at $-0.4 \mathrm{~V}$ vs. RHE in $0.1 \mathrm{M}$ $\mathrm{KHCO}_{3}$; (b) long-term stability studies of $\mathrm{Sn}-\mathrm{Pd} / \mathrm{CNT}-\mathrm{NH}_{2}$ for $\mathrm{CO}_{2}$ electroreduction operated in $0.1 \mathrm{M} \mathrm{KHCO}_{3}$ at $-0.4 \mathrm{~V}$ vs. RHE for $4 \mathrm{~h}$; (c) SEM, and (d) AFM comparison of $\mathrm{Sn}-\mathrm{Pd} / \mathrm{CNT}-\mathrm{NH}_{2}$ before and after 4 hours electrochemical $\mathrm{CO}_{2} \mathrm{RR}$.

scaffold, and $-\mathrm{NH}_{2}$ group which works to both improve conductivity and $\mathrm{CO}_{2}$ capture throughout the catalytic layer. Introducing amino groups, such as in $\mathrm{Pd} / \mathrm{CNT}-\mathrm{NH}_{2}$, served dual purposes as a localized proton source and as an additional $\mathrm{CO}_{2}$ capture site, facilitate even higher catalytic activity and selectivity. To confirm these phenomena and important role of CNT and $-\mathrm{NH}_{2}$ in the $\mathrm{CO}_{2} \mathrm{RR}$, the $\mathrm{FE}_{\text {formate }}$ and $j_{\text {formate }}$ of $\mathrm{Sn}-\mathrm{Pd}$ with $\mathrm{Sn}-\mathrm{Pd} / \mathrm{CNT}-\mathrm{NH}_{2}$ was compared in Fig. $3 \mathrm{c}$ and $\mathrm{d}$ at the potentials of $-0.3 \mathrm{~V}$ to $-0.6 v s$. RHE in $0.1 \mathrm{M} \mathrm{KHCO}_{3}$. It clearly indicates both product selectivity and catalytic activity have been enhanced $\sim 2$-folds at the optimal potential of $-0.4 \mathrm{~V} v s$. RHE in the case of $\mathrm{Sn}-\mathrm{Pd} / \mathrm{CNT}-\mathrm{NH}_{2}$.

Fig. 4a demonstrates the current densities and selectivities of both Sn-Pd/CNT ( $\mathrm{FE}_{\text {formate }}: 83 \%, j_{\text {formate }}$ : $-29.6 \mathrm{~mA} \mathrm{~cm}{ }^{-2}$ ), and $\mathrm{Sn}-\mathrm{Pd} / \mathrm{CNT}-\mathrm{NH}_{2}\left(\mathrm{FE}_{\text {formate }}: 91 \%, j_{\text {formate }}:-39.1 \mathrm{~mA} \mathrm{~cm}{ }^{-2}\right.$ ) at $-0.4 \mathrm{~V}$ vs. RHE were significantly higher than that of Sn-Pd ( $\mathrm{FE}_{\text {formate }}: 19 \%, j_{\text {formate }}:-18.2 \mathrm{~mA} \mathrm{~cm}^{-2}$ ). The long-term, operational stability of $\mathrm{Sn}-\mathrm{Pd} / \mathrm{CNT}-\mathrm{NH}_{2}$ was monitored continuously for $4 \mathrm{~h}$ in $\mathrm{KHCO}_{3}$ at $-0.4 \mathrm{~V}$ vs. RHE (Fig. $4 \mathrm{~b}$ ). The current density $\left(-39 \mathrm{~mA} \mathrm{~cm}^{-2}\right)$ was maintained for the entire duration and $\mathrm{FE}_{\text {formate }}$ remained constant over $90 \%$. No significant decrease in current density and product selectivity was observed during this period SEM (Fig. 4c), atomic force microscopy (AFM) (Fig. 4d), and XPS (Fig. S17, ESI $\dagger$ ) found no significant alterations in surface morphology before and after long-term electrolysis. This phenomenon was further examined and discussed using FTIR and described in detail in the ESI $\dagger$ (Fig. S18).

The ability of the $\mathrm{Sn}-\mathrm{Pd} / \mathrm{CNT}-\mathrm{NH}_{2}$ aerogel to capture and adsorb $\mathrm{CO}_{2}$ was measured at varying temperatures based on the weight change of the aerogel before and after the introduction of $\mathrm{CO}_{2} \cdot{ }^{79} \mathrm{Sn}-\mathrm{Pd} / \mathrm{CNT}-\mathrm{NH}_{2}(12 \mathrm{mg})$ was heated to $110{ }^{\circ} \mathrm{C}$ in a sealed chamber under $\mathrm{N}_{2}$ with a flow rate of $40 \mathrm{sccm}$ to remove any air or existing moisture. After applying $\mathrm{CO}_{2}$, the weight change of the sample during adsorption and desorption process was calculated every $2 \mathrm{~min}$ at $25{ }^{\circ} \mathrm{C}$ under $\mathrm{CO}_{2}$ with a flow rate of $40 \mathrm{sccm}$. The $\mathrm{CO}_{2}$ uptake per mole of $\mathrm{Sn}-\mathrm{Pd} / \mathrm{CNT}-\mathrm{NH}_{2}$ slowly increased over time, with a maximum uptake of $6.89 \mathrm{mmol} \mathrm{g}^{-1}$ over 48 minutes (Fig. S19a, ESI $\dagger$ ). Next, the adsorption of the aerogel was measured at several temperatures under $\mathrm{CO}_{2}$ atmosphere (Fig. S19b, ESI $\dagger$ ). $\mathrm{CO}_{2}$ uptake improved with increasing temperatures, reaching a maximum of $7.82 \mathrm{mmol} \mathrm{g}^{-1}$ at $75{ }^{\circ} \mathrm{C}$. The stability of the aerogel was examined over several adsorption/desorption cycles at $75{ }^{\circ} \mathrm{C}$ and no dramatic change in the level of adsorption was observed.

To obtain insight on the $\mathrm{CO}_{2}$ electroreduction reaction mechanism, Tafel slopes were calculated and performed in Fig. S20 (ESI $\dagger$ ). The slopes were measured to be 97, 84, and $82 \mathrm{mV} \mathrm{dec}{ }^{-1}$, for $\mathrm{Sn}-\mathrm{Pd}, \mathrm{Sn}-\mathrm{Pd} / \mathrm{CNT}$ and $\mathrm{Sn}-\mathrm{Pd} / \mathrm{CNT}-\mathrm{NH}_{2}$, respectively. Achieving smaller Tafel slope values in the case of $\mathrm{Sn}-\mathrm{Pd} / \mathrm{CNT}-\mathrm{NH}_{2}$, suggest that less driving force (overpotential) is required to improve the reaction rate, ${ }^{80,81}$ which is also in agreement with previous reports on the bimetallic Sn-Pd alloy which shown to be highly dependent on the catalysts' surface electronic properties. ${ }^{82}$ The achieved Tafel values are close to the theoretical value for a rapid one-electron transfer step followed by a rate-determining step (RDS). ${ }^{25}$ Reducing $\mathrm{CO}_{2}$ to formate at such low overpotential, ${ }^{25,83}$ suggest that ${ }^{*} \mathrm{OCHO}$ is the key intermediate for the $\mathrm{CO}_{2} \mathrm{RR}$ electroreduction. ${ }^{84}$ The Sn's ideal ${ }^{*} \mathrm{OCHO}$ binding energy supports this phenomenon. These results are also consistent with previous reports on observing * OCHO on Sn-based electrodes using spectroscopic techniques. ${ }^{85,86}$

In summary, using porous, bimetallic Sn-Pd-based aerogels paired with $\mathrm{CNT}-\mathrm{NH}_{2}$, we could significantly increase their catalytic efficiency and product selectivity compared to their monometallic analogues, highlighting the importance of synergistic binding site diversity between Sn and Pd (Table S1, ESI $\dagger$ ). To the best of our knowledge, this is one of the lowest overpotentials that has been reported for bimetallic compounds for $\mathrm{CO}_{2} \mathrm{RR}$ applications (Table S2, ESI $\dagger$ ). ${ }^{30,34,82,87-98}$ The essential role of the $-\mathrm{NH}_{2}$ group in acting as an additional $\mathrm{CO}_{2}$ capture site and as an extra proton source played a significant role in increasing the catalytic activity and selectivity of this system. ${ }^{99,100}$ The remarkable catalytic performance of the Sn$\mathrm{Pd}$ aerogels reported herein make it a promising candidate for $\mathrm{CO}_{2} \mathrm{RR}$ on a large scale.

\section{Conclusions}

In conclusion, we have synthesized and characterized a new class of $\mathrm{Pd}-\mathrm{Sn}$ aerogels outfitted with CNTs and $-\mathrm{NH}_{2}$ groups. In this work, the introduction of binding site diversity increased the current density $\sim 36$-fold higher than its monometallic constituents. The exceptional catalytic performance achieved with $\mathrm{Sn}-\mathrm{Pd} / \mathrm{CNT}-\mathrm{NH}_{2}$ demonstrates high selectivity ( FE $_{\text {formate: }}$ 91\%), current density $\left(j_{\text {formate }}:-39.1 \mathrm{~mA} \mathrm{~cm}^{-2}\right)$, and stability at low overpotential of $0.4 \mathrm{~V}$. The potential for 
bimetallic tunability and the unique 3D structure of aerogels facilitated greater $\mathrm{CO}_{2}$ capture and conversion and makes them an attractive class of electrocatalysts for electroreduction of $\mathrm{CO}_{2}$ to value-added materials.

\section{Conflicts of interest}

There are no conflicts to declare.

\section{Acknowledgements}

This work was supported by Natural Sciences and Engineering Research Council of Canada (NSERC-DG-2016-06122), and the University of Toronto. We gratefully acknowledge Dr Tom Burdyny and Marcel Bus at the Delft University of Technology for their support on this work.

\section{Notes and references}

1 M. Meinshausen, N. Meinshausen, W. Hare, S. C. B. Raper, K. Frieler, R. Knutti, D. J. Frame and M. R. Allen, Nature, 2009, 458, 1158-1162.

2 M. Usman, M. Humayun, M. D. Garba, L. Ullah, Z. Zeb, A. Helal, M. H. Suliman, B. Y. Alfaifi, N. Iqbal, M. Abdinejad, A. A. Tahir and H. Ullah, Nanomater., 2021, 11.

3 J. He, C. Wu, Y. Li and C. Li, J. Mater. Chem. A, 2021, 9, 19508-19533.

4 M. Abdinejad, C. Dao, B. Deng, F. Dinic, O. Voznyy, X. Zhang and H.-B. Kraatz, ACS Sustainable Chem. Eng., 2020, 8, 9549-9557.

5 M. Abdinejad, M. N. Hossain and H.-B. Kraatz, RSC Adv., 2020, 10, 38013-38023.

6 L. Fan, C. Xia, F. Yang, J. Wang, H. Wang and Y. Lu, Sci. Adv., 2020, 6, eaay3111.

7 D. Lei, Q. Qing, W. Pei, Z. Xiaojing, H. Chengyi, L. Pengxin, Q. Ruixuan, C. Mei, O. Daohui, X. Chaofa, M. Shiguang, W. Binghui, F. Gang, Z. Peng and Z. Nanfeng, Sci. Adv., 2021, 3, e1701069.

8 M. Abdinejad, L. F. B. Wilm, F. Dielmann and H. B. Kraatz, ACS Sustainable Chem. Eng., 2021, 9, 521-530.

9 S. A. Al-Tamreh, M. H. Ibrahim, M. H. El-Naas, J. Vaes, D. Pant, A. Benamor and A. Amhamed, ChemElectroChem, 2021, 8, 3207-3220.

10 Y. Ling, Q. Ma, Y. Yu and B. Zhang, Trans. Tianjin Univ., 2021, 27, 180-200.

11 P. Ding, H. Zhao, T. Li, Y. Luo, G. Fan, G. Chen, S. Gao, X. Shi, S. Lu and X. Sun, J. Mater. Chem. A, 2020, 8, 21947-21960.

12 Y. C. Li, Z. Wang, T. Yuan, D.-H. Nam, M. Luo, J. Wicks, B. Chen, J. Li, F. Li, F. P. G. de Arquer, Y. Wang, C.-T. Dinh, O. Voznyy, D. Sinton and E. H. Sargent, J. Am. Chem. Soc., 2019, 141, 8584-8591.

13 B. Jiang, X.-G. Zhang, K. Jiang, D.-Y. Wu and W.-B. Cai, J. Am. Chem. Soc., 2018, 140, 2880-2889.
14 N. Zouaoui, B. D. Ossonon, M. Fan, D. Mayilukila, S. Garbarino, G. de Silveira, G. A. Botton, D. Guay and A. C. Tavares, J. Mater. Chem. A, 2019, 7, 11272-11281.

15 P. Deng, H. Wang, R. Qi, J. Zhu, S. Chen, F. Yang, L. Zhou, K. Qi, H. Liu and B. Y. Xia, ACS Catal., 2020, 10, 743-750.

16 S. Liu, X. F. Lu, J. Xiao, X. Wang and X. W. (David) Lou, Angew. Chem., Int. Ed., 2019, 58, 13828-13833.

17 L. Lu, X. Sun, J. Ma, Q. Zhu, C. Wu, D. Yang and B. Han, Sci. China: Chem., 2018, 61, 228-235.

18 S. Liu, J. Xiao, X. F. Lu, J. Wang, X. Wang and X. W. (David) Lou, Angew. Chem., Int. Ed., 2019, 58, 8499-8503.

19 Yiliguma, Z. Wang, C. Yang, A. Guan, L. Shang, A. M. AlEnizi, L. Zhang and G. Zheng, J. Mater. Chem. A, 2018, 6, 20121-20127.

20 M. Abdinejad, I. Santos da Silva and H. B. Kraatz, J. Mater. Chem. A, 2021, 9, 9791-9797.

21 W. Luo, W. Xie, M. Li, J. Zhang and A. Züttel, J. Mater. Chem. A, 2019, 7, 4505-4515.

22 W. Zhu, B. M. Tackett, J. G. Chen and F. Jiao, Top. Curr. Chem., 2018, 376, 41.

23 L. Xie, J. Liang, C. Priest, T. Wang, D. Ding, G. Wu and Q. Li, Chem. Commun., 2021, 57, 1839-1854.

24 X. An, S. Li, A. Yoshida, Z. Wang, X. Hao, A. Abudula and G. Guan, ACS Sustainable Chem. Eng., 2019, 7, 9360-9368.

25 S. Zhao, S. Li, T. Guo, S. Zhang, J. Wang, Y. Wu and Y. Chen, Nano-Micro Lett., 2019, 11, 62.

26 F. Cheng, X. Zhang, K. Mu, X. Ma, M. Jiao, Z. Wang, P. Limpachanangkul, B. Chalermsinsuwan, Y. Gao, Y. Li, Z. Chen and L. Liu, Energy Technol., 2021, 9, 2000799.

27 Y. Wei, J. Liu, F. Cheng and J. Chen, J. Mater. Chem. A, 2019, 7, 19651-19656.

28 C. M. Gabardo, A. Seifitokaldani, J. P. Edwards, C. T. Dinh, T. Burdyny, M. G. Kibria, C. P. O'Brien, E. H. Sargent and D. Sinton, Energy Environ. Sci., 2018, 11, 2531-2539.

29 N. Hoshi, M. Kato and Y. Hori, J. Electroanal. Chem., 1997, 440, 283-286.

30 Y. Chen and M. W. Kanan, J. Am. Chem. Soc., 2012, 134, 1986-1989.

31 C. H. Lee and M. W. Kanan, ACS Catal., 2015, 5, 465-469.

32 K. P. Kuhl, E. R. Cave, D. N. Abram and T. F. Jaramillo, Energy Environ. Sci., 2012, 5, 7050-7059.

33 S. Zhang, P. Kang and T. J. Meyer, J. Am. Chem. Soc., 2014, 136, 1734-1737.

34 X. Zheng, Y. Ji, J. Tang, J. Wang, B. Liu, H.-G. Steinrück, K. Lim, Y. Li, M. F. Toney, K. Chan and Y. Cui, Nat. Catal., 2019, 2, 55-61.

35 Y. Xu, S. Jin, H. Xu, A. Nagai and D. Jiang, Chem. Soc. Rev., 2013, 42, 8012-8031.

36 N. Chaoui, M. Trunk, R. Dawson, J. Schmidt and A. Thomas, Chem. Soc. Rev., 2017, 46, 3302-3321.

37 W. Luo, J. Zhang, M. Li and A. Züttel, ACS Catal., 2019, 9, 3783-3791.

38 H. Ge, Z. Gu, P. Han, H. Shen, A. M. Al-Enizi, L. Zhang and G. Zheng, J. Colloid Interface Sci., 2018, 531, 564-569.

39 G. Wang, L. Zhang and J. Zhang, Chem. Soc. Rev., 2012, 41, 797-828. 
40 N. Hüsing and U. Schubert, Angew. Chem., Int. Ed., 1998, 37, 22-45.

41 A. C. Pierre and G. M. Pajonk, Chem. Rev., 2002, 102, 4243-4266.

42 R. Du, W. Jin, H. Wu, R. Hübner, L. Zhou, G. Xue, Y. Hu and A. Eychmüller, J. Mater. Chem. A, 2021, 9, 17189-17197.

43 C. Ziegler, A. Wolf, W. Liu, A.-K. Herrmann, N. Gaponik and A. Eychmüller, Angew. Chem., Int. Ed., 2017, 56, 13200-13221.

44 X. Jiang, R. Du, R. Hübner, Y. Hu and A. Eychmüller, Matter, 2021, 4, 54-94.

45 R. Du, X. Jin, R. Hübner, X. Fan, Y. Hu and A. Eychmüller, Adv. Energy Mater., 2020, 10, 1901945.

46 C. Chen, X. Sun, X. Yan, Y. Wu, H. Liu, Q. Zhu, B. B. A. Bediako and B. Han, Angew. Chem., Int. Ed., 2020, 59, 11123-11129.

47 M. Wang, B. Zhang, J. Ding, N. Xu, M. T. Bernards, Y. He and Y. Shi, ACS Sustainable Chem. Eng., 2020, 8, 4983-4994.

48 M. Abdinejad, C. Ferrag, M. N. Hossain, M. Noroozifar, K. Kerman and H. B. Kraatz, J. Mater. Chem. A, 2021, 9, 12870-12877.

49 Z. Chen, S. Yao and L. Liu, J. Mater. Chem. A, 2017, 5, 24651-24656.

50 D. D. Zhu, J. L. Liu and S. Z. Qiao, Adv. Mater., 2016, 28, 3423-3452.

51 D. Gao, H. Zhou, F. Cai, D. Wang, Y. Hu, B. Jiang, W.-B. Cai, X. Chen, R. Si, F. Yang, S. Miao, J. Wang, G. Wang and X. Bao, Nano Res., 2017, 10, 2181-2191.

52 J. Wu, R. M. Yadav, M. Liu, P. P. Sharma, C. S. Tiwary, L. Ma, X. Zou, X.-D. Zhou, B. I. Yakobson, J. Lou and P. M. Ajayan, ACS Nano, 2015, 9, 5364-5371.

53 M. Abdinejad, A. Seifitokaldani, C. Dao, E. H. Sargent, X. A. Zhang and H. B. Kraatz, ACS Appl. Energy Mater., 2019, 2, 1330-1335.

54 M. Abdinejad, Z. Mirza, X. Zhang and H.-B. Kraatz, ACS Sustainable Chem. Eng., 2020, 8, 1715-1720.

55 M. Abdinejad, C. Dao, X. Zhang and H. B. Kraatz, J. Energy Chem., 2021, 58, 162-169.

56 D. Wu, X. Chen, S. Lu, Y. Liang, F. Xu and R. Fu, Microporous Mesoporous Mater., 2010, 131, 261-264.

57 N. Roy, A. Ejaz and S. Jeon, Appl. Surf. Sci., 2021, 151973.

58 M. Terrones, W. K. Hsu, A. Schilder, H. Terrones, N. Grobert, J. P. Hare, Y. Q. Zhu, M. Schwoerer, K. Prassides, H. W. Kroto and D. R. M. Walton, Appl. Phys. A: Mater. Sci. Process., 1998, 66, 307-317.

59 X. Liu, X. Li, D. Wang, R. Yu, Y. Cui, Q. Peng and Y. Li, Chem. Commun., 2012, 48, 1683-1685.

60 A. M. Sheikh, E. L. Silva, L. Moares, L. M. Antonini, M. Y. Abellah and C. F. Malfatti, Am. J. Min. Metall., 2014, 2, 64-69.

61 A. Eshghi and M. kheirmand, Int. J. Hydrogen Energy, 2017, 42, 15064-15072.

62 S.-Y. Yang, K.-H. Chang, H.-W. Tien, Y.-F. Lee, S.-M. Li, Y.-S. Wang, J.-Y. Wang, C.-C. M. Ma and C.-C. Hu, J. Mater. Chem., 2011, 21, 2374-2380.
63 Y. Simsek, L. Ozyuzer, A. T. Seyhan, M. Tanoglu and K. Schulte, J. Mater. Sci., 2007, 42, 9689-9695.

64 N. Tsud, T. Skála, F. Šutara, K. Veltruská, V. Dudr, S. Fabík, L. Sedláček, V. Cháb, K. C. Prince and V. Matolín, Surf. Sci., 2005, 595, 138-150.

65 A. F. Lee, C. J. Baddeley, M. S. Tikhov and R. M. Lambert, Surf. Sci., 1997, 373, 195-209.

66 C. Tayran and M. Çakmak, Eur. Phys. J. B, 2019, 92, 240.

67 S. M. Kozlov, F. Viñes and A. Görling, J. Phys. Chem. C, 2012, 116, 7360-7366.

68 F. Daneshvar, H. Chen, K. Noh and H.-J. Sue, Nanoscale Adv., 2021, 3, 942-962.

69 E. P. Randviir, Electrochim. Acta, 2018, 286, 179-186.

70 M. Zareie Yazdan-Abad, M. Noroozifar, A. R. Modaresi Alam and H. Saravani, J. Mater. Chem. A, 2017, 5, 10244-10249.

71 W. Deng, L. Zhang, L. Li, S. Chen, C. Hu, Z.-J. Zhao, T. Wang and J. Gong, J. Am. Chem. Soc., 2019, 141, 2911-2915.

72 S. Levine and A. L. Smith, Discuss. Faraday Soc., 1971, 52, 290-301.

73 Y. Cheng, P. Hou, H. Pan, H. Shi and P. Kang, Appl. Catal., B, 2020, 272, 118954.

74 V. Yarlagadda, G. Lin, P. Y. Chong and T. Van Nguyen, J. Electrochem. Soc., 2015, 163, A5134-A5143.

75 M. E. Birch, T. A. Ruda-Eberenz, M. Chai, R. Andrews and R. L. Hatfield, Ann. Occup. Hyg., 2013, 57, 1148-1166.

76 Y. He, H. Zhu, Q. Liu, J. Liu, H. Zhang, R. Li, Z. Li and J. Wang, RSC Adv., 2016, 6, 70999-71005.

77 V. Bogdanovskaya, I. Vernigor, M. Radina, V. Andreev, O. Korchagin and V. Novikov, Catalysis, 2020, 10.

78 M. Abdinejad, C. Dao, B. Deng, M. E. Sweeney, F. Dielmann, X. Zhang and H. B. Kraatz, ChemistrySelect, 2020, 5, 979-984.

79 X. Xu, C. Song, J. M. Andresen, B. G. Miller and A. W. Scaroni, Energy Fuels, 2002, 16, 1463-1469.

80 Q. Lu and F. Jiao, Nano Energy, 2016, 29, 439-456.

81 Q. Lu, J. Rosen, Y. Zhou, G. S. Hutchings, Y. C. Kimmel, J. G. Chen and F. Jiao, Nat. Commun., 2014, 5, 3242.

82 X. Bai, W. Chen, C. Zhao, S. Li, Y. Song, R. Ge, W. Wei and Y. Sun, Angew. Chem., Int. Ed., 2017, 56, 12219-12223.

83 J. T. Feaster, C. Shi, E. R. Cave, T. Hatsukade, D. N. Abram, K. P. Kuhl, C. Hahn, J. K. Nørskov and T. F. Jaramillo, ACS Catal., 2017, 7, 4822-4827.

84 J. S. Yoo, R. Christensen, T. Vegge, J. K. Nørskov and F. Studt, ChemSusChem, 2016, 9, 358-363.

85 M. F. Baruch, J. E. Pander, J. L. White and A. B. Bocarsly, ACS Catal., 2015, 5, 3148-3156.

86 A. Dutta, A. Kuzume, M. Rahaman, S. Vesztergom and P. Broekmann, ACS Catal., 2015, 5, 7498-7502.

87 D. H. Won, C. H. Choi, J. Chung, M. W. Chung, E.-H. Kim and S. I. Woo, ChemSusChem, 2015, 8, 3092-3098.

88 X. Zheng, P. De Luna, F. P. García de Arquer, B. Zhang, N. Becknell, M. B. Ross, Y. Li, M. N. Banis, Y. Li, M. Liu, O. Voznyy, C. T. Dinh, T. Zhuang, P. Stadler, Y. Cui, X. Du, P. Yang and E. H. Sargent, Joule, 2017, 1, 794-805. 
89 L. Fan, Z. Xia, M. Xu, Y. Lu and Z. Li, Adv. Funct. Mater., 2018, 28, 1706289.

90 B. Kumar, V. Atla, J. P. Brian, S. Kumari, T. Q. Nguyen, M. Sunkara and J. M. Spurgeon, Angew. Chem., Int. Ed., 2017, 56, 3645-3649.

$91 \mathrm{~J} . \mathrm{Wu}$, F. G. Risalvato, S. Ma and X.-D. Zhou, J. Mater. Chem. A, 2014, 2, 1647-1651.

92 W. J. Dong, C. J. Yoo and J.-L. Lee, ACS Appl. Mater. Interfaces, 2017, 9, 43575-43582.

93 W. Luc, C. Collins, S. Wang, H. Xin, K. He, Y. Kang and F. Jiao, J. Am. Chem. Soc., 2017, 139, 1885-1893.

94 V.S. K. Yadav, Y. Noh, H. Han and W. B. Kim, Catal. Today, 2018, 303, 276-281.
95 Y. Zhao, J. Liang, C. Wang, J. Ma and G. G. Wallace, $A d v$. Energy Mater., 2018, 8, 1702524.

96 J. He, K. E. Dettelbach, A. Huang and C. P. Berlinguette, Angew. Chem., Int. Ed., 2017, 56, 16579-16582.

97 S. Y. Choi, S. K. Jeong, H. J. Kim, I.-H. Baek and K. T. Park, ACS Sustainable Chem. Eng., 2016, 4, 1311-1318.

98 A. Zhang, R. He, H. Li, Y. Chen, T. Kong, K. Li, H. Ju, J. Zhu, W. Zhu and J. Zeng, Angew. Chem., Int. Ed., 2018, 57, 10954-10958.

99 C. Costentin, S. Drouet, G. Passard, M. Robert and J. M. Savéant, J. Am. Chem. Soc., 2013, 135, 9023-9031.

100 C. Costentin, S. Drouet, M. Robert and J. M. Savéant, Science, 2012, 338, 90-94. 